\title{
Political Freedom and Intellectual Property Rights: Conflict of values ${ }^{1}$
}

\author{
Ivo Telec ${ }^{2}$
}

\section{Faculty of Law, Palacký University Olomouc, Czech Republic email: ivo.telec@upol.cz}

TELEC, Ivo. Political Freedom and Intellectual Property Rights: Conflict of values. International and Comparative Law Review, 2015, vol. 15, no. 2, pp. 7-22. DOI: 10.1515/iclr-2016-0033.

\begin{abstract}
The paper critically observes the current legal and political happenings around the international multilateral Anti-Counterfeiting Trade Agreement (ACTA), including criticism for its rejection by the European Parliament in the year of 2012. This example is treated in the sense of the collision of values in today's information society, e.g. political freedom on the one hand, and intellectual property rights on the other. The collision of values is balanced fairly by the laws, for example by the statutory licenses and compulsory licenses, too. This text also critically considers some aspects of the contemporary political ideology of information. The author considers the majority of the European public reaction to the Anti-Counterfeiting Trade Agreement as fearful, irrational and populist by politicians. "Electronic Violence" remains violence like any other and everyone must have the courage to face it. The information society itself is based on the same values as any other human society. Likewise, the information society is prone to various vices, such as greed for foreign assets without any compensation. This greed is only masked by political rhetoric about freedom and human rights. Therefore, it is necessary to distinguish between legal ideology of information from legally regulated economic shifts.
\end{abstract}

Keywords: Anti-Counterfeiting Trade Agreement (ACTA), political freedom, intellectual property, values of the information society, conflicts of values and their context, anonymous protest movement.

"The economic well-being of the Union relies on sustained creativity and innovation. Therefore, measures for their effective protection are indispensable in ensuring its future prosperity."3

1 The author presented the basic theses at the plenary session of the Trnava Legal Days conference, held by the Trnava University, Faculty of Law on 20-21 September 2012, on the topic System of values of law and its reflection in legal theory and practice. Formerly published in Czech in Právník, Vol. 152, No. 3, pp. 209-221. [Politická svoboda a duševní vlastnictví: střet hodnot.]

2 Professor and Head of the Department of Civil Law and Civil Procedure, Faculty of Law, Palacký University Olomouc (CZE); email: ivo.telec@upol.cz

3 Rec. (1) Regulation (EU) of the European Parliament and of the Council (EU) No. 386/2012 of 19 April 2012, on entrusting the Office for Harmonisation in the Internal Market (Trade Marks and Designs) with tasks related to the enforcement of intellectual 


\section{Introduction}

This article will provide a critical review of the current legal and political happenings relating to the multilateral international Anti-Counterfeiting Trade Agreement (ACTA), including the critique of disagreement with the conclusion thereof from the side of the European Parliament in 2012. On that example we will elaborate the conflict of values in the current information society, i.e. the conflict between political freedom on one hand and the right to intellectual property on the other one. As concerns legislation, the collision of those values is solved by a relatively well-balanced manner; by legal or official (forced) licences. The text also provides a critical view on certain aspects of the current information ideology and partisan policies originating therein.

The multilateral international Anti-Counterfeiting Trade Agreement, known under the abbreviation ACTA, was signed in 2011 after eleven rounds of proceedings. The Czech Republic added its signature in early 2012. From legal viewpoint, the Agreement does not bring anything new for us in principle. The purpose of the Agreement is more effective enforcement of existing rights, not implementation of new ones. The Trade Agreement facilitates expansion of certain standards of implementation of rights by virtue of the long ratified multilateral international Agreement on Trade Related Aspects of Intellectual Property Rights (TRIPS) of 1994, (Notification No. 191/1995 Coll.), outside Member States of the world Trade Organisation and at the same time it expands the legal framework of the intellectual property protection, as it has been practised for several years for example in the European Union and its Member States, or in the European Economic Area, respectively, and in several third countries, and other signatory states. This way the Trade agreement, concluded from the trading and legally-political policy of the U.S.A. bolsters, at least indirectly, the importance of the intellectual property protection in the world Trade Organisation. Acceptance of this trade agreement as a part of the Czech legal order would not require, by all accounts, any legislative modifications, or perhaps only immaterial ones. In fact, the rules which the Agreement is based on are internally effective here from 2006 at least, as a result of implementation of Community Law, ${ }^{4}$ to say nothing about the rules that give similar grounds to the TRIPS Agreement of 1994.

property rights, including the assembling of public - and private sector representatives as a European Observatory on Infringements of Intellectual Property rights, (Official Journal L 129, 16. 5. 2012, p. 1).

4 I deal with these legal issues elsewhere; see Telec, I.: ACTA: Důvod k obavám? Právní rádce, Vol. 20, 2012, vol. 7, p. 16-19. ACTA nejsou akta ani akty (ACTA is neither dossier or acts), Jiné právo, 18. 2. 2012, http://jinepravo.blogspot.cz/2012/02/ivo-telec-acta-nejsou-aktaani-akty.html. Further, Padělané léky, Jiné právo, 28. 2. 2012, http://jinepravo.blogspot. cz/2012/02/ivo-telec-padelane-leky.html. See also discussions to both the papers. The full version of my treatise under the title ACTA nejsou akta ani akty (ACTA is neither dossier or acts), dedicated in particular to students' discussion, see: $\boldsymbol{h t t p : / / w w w . e l s a . c z /}$ page/9522/, [quoted on 22. 8. 2012]. When writing this article, I partly followed from that full version. The result is an updated and substantially revised shape of a smaller part of the 
Then, why were there so many media and street storms in Europe in 2012? Why some signatory states came to political "suspensions" of domestic ratifications, governmental retreats from previously agreed grounds and eventually to rejection of the consent for the European Parliament to conclude the trade agreement?

The reader will find the answer to that question in the title of the following chapter.

\section{Disinformation, fearfulness, irrationality and political populism}

In the European Parliament, composed mostly by legal laymen, the multilateral Anti-Counterfeiting Trade Agreement, submitted by the council, was criticised for its alleged vagueness, possibility of misinterpretation, alleged unbalance between copyright and fundamental rights of Internet users, threat of possible jeopardy to civil liberties, and the like. ${ }^{5}$ The reproaches were largely legally ill-

full version of February 2012.

Cf. my statement published in the Lemur, the Masaryk University student portal of 17. 3 . 2012: "The commotion around ACTA is false and misleading. It is a political demagogy of so-called pirate political parties and an expression of a certain political ideology that does not have anything in common with law or international trade. In essence, it is an expression of total social disorientation, personal human immaturity and in particular of an extraordinary paranoia towards the state bodies, on which, however, a standard social communication cannot be build."; see http://lemur.mu/nazory/85-publicistika/1067-pravnik-ivo-telecrozruch-kolem-acta-je-politicka-demagogie; [quoted on 28. 8. 2012]. See also the quoted article in Právní rádce.

5 See e.g. Schulz, M.: Neúspěch ACTA byl svátkem demokracie (ACTA’s failure was a feast of democracy). MF Dnes, 12. 7. 2012, p. A 13. The author of the quoted journalistic article is the president of the European Parliament. According to Schulz, most of the EP Members and many citizens believe that ACTA is "... much too unclear and it opens space to various misinterpretations, bullying and intrusions into the privacy, civic rights, creativity, innovations and the free flow of information". "Were it really for the protection of goods from counterfeiting, either of clothes or medicals, neither me not any of my colleagues would refuse ACTA." In short, perhaps it is a "devil's work of the U.S.A.", whose true objective, soon enough revealed by the alert European Parliament Members, should be establishment of the global political totality under the transparent pretext of protection of immovable assets, as we could add sarcastically. It is only pity that the President of the European Parliament did not tell the public that the European Community acceded to a similar agreement, the TRIPS, belonging to the legal pillars of the World Trade Organisation, as early as in 1994. Also similar is the "original" law of the European Union including European Parliament and Council Directives from 2001 and 2004. If the ACTA's failure was a "feast of democracy", then it was a mourning day for law and justice. The people-ruling power technique, shielded by letters of the frightened part of the people, controlled by negative emotions, prevailed over reason, trade, law, and professionalism, including rational attitude of the European Commission, that (perhaps with some alibism) submitted the international treaty to the court of Justice for assessment of conformity thereof with the Treaty on the functioning of the European Union. However, the European Parliament, perhaps in some kind of the Members' "plebeian pride" mood did not wait for the result of the legal determination by the addressed EU body. "Since the rejection of ACTA, the European Parliament 
founded. Also, the Trade agreement was criticised for a certain democratic deficit at the preparation thereof. Even would that really be so, decisive is the final content of the legal rule that is no way deviating from what has long been valid in the European Union, European Economic Area and the Czech Republic, anyway. ${ }^{6}$ We may as well say it is legally dilettantish to criticise a universal international agreement, signed "across the continents", for lack of details. Agreements of this kind have to leave space for implementation by national bodies of public power, accordingly to the rules of the local legal culture. An opposing view would be almost an anarchistic expression of distrust towards public power bodies.

Not only from the legal viewpoint, but also by common sense the politically presented reproaches were fundamentally groundless. Obviously, anything can be misused, for example a car may become a weapon under certain circumstances. The possibility of incorrect interpretation of law may potentially threaten at everything, though only when we do not know or use reviewable and scientifically grounded methods of interpretation of law, including interpretation of international treaties. However, one must understand that vast majority of the European Parliament members, as well as those of national parliaments, do know absolutely nothing about those methods. Should civil liberties be possibly threatened by fighting back against counterfeiting, there will, of course, apply the use of the jurisprudential method of balancing of colliding principles or values, which is a methodological feature of the juridical science. ${ }^{7}$ Therefore, we cannot get rid of

has been an institution that must be seriously taken into account," President Schulz concludes his article. Unfortunately, he has a point at that. However, let's not forget which way election campaigns to the European Parliament (and other bodies) are often led, and what (albeit unrealistic) election vows make it possible (also in a populist manner) to gain votes. The technique of democracy is merely a technique of the quest for power and a technique of performance thereof. Democracy as such does not necessarily bring legitimacy in the system of values as concerns welfare. After all, many authoritarians or even dictators were democratically elected by majority.

The political statement that "borders between commercial and non-commercial use is not completely clear" belongs among "legal jewels"; point 29 of the opinion of the European Parliament Committee for Civil Liberties, Justice and home Affairs of 4. 6. 2012, addressed to the Committee for International Trade. Petitioner Droutsas. Likewise, "important distinguishing" between "non-commercial downloading in small scale and a private one" (ibid.) is irrelevant in the legal sense, since non-commercial downloading from the Internet, regardless its scope (scale), as a rule falls within public domain; i.e. it is a free use. According to Czech law, at least. (source: see below)

For more about ACTA see also news at the European Parliament portal: http://www.europarl.europa.eu/news/cs/headlines/content/20120220FCS38611/html/V\%C5\%Ale-copot\%C5\%99ebujete-v\%C4\%9Bd\%C4\%9Bt-o-ACTA, [quoted on 28. 8. 2012].

6 It is important that all preparatory material is made accessible, so as it be possible to use the historic method of interpretation of the international treaty, i.e. interpretation reflecting the history of establishment thereof.

7 In all accounts, the knowledge of the world legal methodology cannot be expected from prevailingly legally lay politicians, when often poorly educated lawyers lack it (in particular in the countries with post-soviet legal education). On the other hand, using of common 
the feeling that the members of parliament who are laymen in law succumbed to the targeted and massive disinformation campaign, considerably supported by political parties united in the Pirate Parties International. Common sense gave way to political populism, suspiciousness, distrust, and irrationalism, where in certain cases the Anti-Counterfeiting Trade Agreement was criticised for what it even does not contain. ${ }^{8}$ Hence, the Trade Agreement has become an out-of-law political symbol of the "threat of unfreedom for the Internet", something that is necessary to fight against, and started to live its own "political life", outside common economic exchange. It is not necessary to add that within the given context of international trade it has become an inappropriate symbol. The substance and purpose of this Agreement is of an international trade nature and it is not related whatsoever to civic liberties that are otherwise necessary to protect. ${ }^{9}$

In my own experience gained at meetings with Czech university students, many ACTA opponents have not ever read the Agreement, or started reading it but have not finished it, or did not understand its legal text, professional language, legal terminology and context. The less they knew, the more loud they usually shouted, they let themselves get misled by some political party members and demonstrated their political attitudes against something what they could not comprehend, or, against what they may have viewed as a possible civic danger, but what did not have anything in common with the given issue of the Trade Agreement. However, expressions of demonstrations by "vox populi", irrational and filled with irritated emotions, occur both in the history and today.

Therefore, our citizen's appreciation belongs to the political attitude of the minority even in the European Parliament that preserved common sense, ability to make its own judgement, orientation in legal issues and did not succumb to mass emotions, fearfulness or political populism. Similarly, the same may be complimentarily said about the European Commission.

Undoubtedly, it is psychologically and politically interesting how some Czech parliamentary or even governmental political parties let themselves get politically influenced, quite irrationally, by negative emotions and ideology of rather marginal political parties like the Česká pirátská strana (Czech Pirate Party) belonging to the Pirate Parties International. It is a political party that has long been enjoying publicly declared support from the ideologically sharp, extreme, and politically mostly demagogic Internet Pirate News, with which the Party is also

sense can be expected from them.

8 For example, ACTA does not include prohibition of the Internet use for the law breaker ("disconnection" from the Internet) or prohibits downloading of so far protected artworks from the Internet and their saving to computer memories for non-commercial personal use. All that was possible in here before ACTA is to be possible after it. And, on the contrary, what was prohibited before ACTA is to be prohibited after it.

9 It is all right, of course, that the question of accordance of ACTA with the EU Charter of Fundamental Rights was on the agenda. 
personally interlinked, or from whose ideological and media support it directly extracts political capital.

At least, to the light is brought some amount of social disorientation or even hypocrisy of some parliamentary and governmental parties and their interest in themselves, short-sightedly manifested outwardly by populism. This happens instead of legitimately expectable sustained public interest in public order on the international market, which, however, requires factuality, deliberation, knowledge of the matter and civil courage to call things their proper names. And also a piece of wisdom (and justice). Not only as a political calculation on what may be medially favourable right now (read: catchy for some part of the people) for a certain political corporation.

As regards the political proclamation of the Polish and consequently similarly Czech Prime minister on "suspension" of ACTA ratification due to the need of its "profound analysis", we may say only the following. Was not ACTA profoundly inspected prior to its official undersigning, to which the President of the Republic authorised the Ambassador, on the basis of recommendation by the government?

If this Trade Agreement had not really been properly examined in advance, then the government would have perpetrated defective administration of public affairs, since upon execution of public power the Government would have acted at least in an irresponsible or non-professional way. However, if ACTA was profoundly examined in advance (of which I am convinced, also with the knowledge of the injured part of the Czech public administration) and recommended for signature, whereas the Czech Prime Minister politically stepped aside only following the electronic violence by the "pirates", then we would have a weak politician in the head of the government. Or a man who does not trust his own officers, who by all accounts have done a good (and casual) job. In the better case, concerned would be only a tactical manoeuvre until the time that electronic protection of governmental servers against future attacks by the "people" improves. ... In the end, you will not harm anyone by a political promise of "profound analysis". Even such a promise can be understood in violent times.

It is only pity that we do not have a political party with the political courage to publicly proclaim that ideological objective of the electronic violence on the state and public property may be the thirst for others' private assets regardless the will of the owner (producer and investor). In other words, almost obsessive desire or immense greed (and immaturity) of some "members of the information society" (some juveniles, in particular) to whenever and wherever comfortably and for free enjoy themselves for other people's money spent on creative investments, which may be dressed on the surface in politically sexy phrases about "the freedom of information". We should understand that as "the freedom" of public performance of others' movies and music for their own profit without payment and 
their downloading from the Internet, also free of charge. Furthermore, all this is required under the economic conditions on the market when the same is done to the detriment of those who legally (i.e. under licence) make music or movies accessible to the public against payment by their customers. ${ }^{10}$

Interesting from political viewpoint is, how far some politicians, even those who declare themselves 'right-wing', let themselves get influenced - maybe unwittingly and without the knowledge of social reality - by the current political ideology of e-Marxism. This political ideology is characterised by a high degree of social naivety flowing "out of time and space", that may recall the naive idea of some city children that "cow is blue", because they know cows only from the Milka brand chocolate, packaged in blue. We may not be far from truth to say

10 See e.g. in the Czech lands available Internet music on-line shops like Supraphonline, MusicJet or Bontonline, or foreign iTunes Store or Deezer. Further see also the Czech Supraphon YouTube Channel. On-line video rental shops like Topfun, Voyo and O2 TV: Videotéka also operate on the Czech market.

Further, see officially registered providers of audiovisual services on demand (video on demand) available in the Czech Republic and not only via electronic communication network but also via cable lines. As on June 10, 2012 the Council for Radio and Television Broadcasting officially registered 107 such kinds of services in total. The number of providers is somewhat smaller since some of them provide several such services; see e.g. Video Seznam, t-music, Doc Alliance Films, Cinema.cz, O2 TV: Videotéka etc. Further, in the Czech market there were 130 publishers in 2012 offering e-books and licences to the public use of photographs through internet photo banks; see e.g. Fotobanka ČTK, etc.

The above mentioned cases concern established new business models of the "society of networks" that correspond with the current environment of the "digital and Internet age". However, the new business models permanently face a rather large unfair competition by some entrepreneurs - providers of storage of information services on the Internet (providers of public storages of videos, etc.) as well as some customers of those services if they have gained the status of sharer of non-licensed foreign products (e.g. full-length movies), unlike the sharers of their own or agreed foreign videos, recordings or photographs generally intended for free sharing in the public.

In addition to the new business models there are, of course, new alternative non-commercial models; see e.g. the Czech versions of Google Maps, Wikipedia, various offers of "open source" or "open access" kind or "non-proprietary software" etc., including offers of freeof-charge use of employees' scientific works by some institutions, e.g. Masaryk University in Brno, etc. Cf. also the option to use the Czech version of the Creative Commons or the private-law system of little limiting copyright licences.

Therefore, when we hear political calls for "new models", it is necessary to answer that new models have (in this country, too) been introduced and used both in commercial and non-commercial manner. It is true that we may come across various imperfections as concerns contents or technology, which, however, undergo remedial development and improvement.

Considering the current circumstances, there is no wonder about some (also international) demands for increased repression (cf. e.g. some provisions of ACTA) when these new models (not to mention the "old" ones) are being constantly attacked both on domestic and international markets, sometimes with the support from some information-political ideologists of a communist or anarchistic orientation, or with a direct backup by e.g. the Czech Pirate Party. 
that some children would think that acted adventure movies are "born in a computer" by a randomly generated data.

There should be noted though, without improper trivialisation, that at least a part of the current information-political ideology is in principle comparable to some ages-old thoughts of communistic nature. In essence, it is an off-spring of the communist ideology, unrealistically counting with the materialistic "paradise on Earth". The specific soviet communistic political model of "socialist copyright law" was abandoned in Czechoslovakia immediately after 1989. Under a political force, we tested this "model of tomorrow" for forty years and we eventually found out what should and could have been clear to us all from the very beginning, i.e. that it does not work. The attempts to break away from the soviet model that occurred here in law policy around 1968 were abandoned by the communists shortly afterwards, politically prohibited and ideologically criticised. Exponents of those attempts were politically and professionally cut down and often suffered civil persecution for many years.

\section{Values of the society of information (virtues and vices)}

Currently, at least in the West, we commonly speak about civic society, information society, or knowledge society, etc. We do so in accordance with our political ideology, through which we express our political opinions, thoughts, theories and ideas on the world or human society. In our context, we will adhere to the term information society and its value anchoring.

What values are typical for the information society?

There are several of them. First, it is the freedom of information and information mutuality or solidarity ("brotherhood") that may be defined also by common beneficial effect (usefulness) of "information" of all kinds. To be applicable, general usefulness of information requires legally and technically (materially) comfortable access to information. However, not necessarily always free of charge. By far not always is concerned information gained through public means.

From a legal point of view we may say that the prerequisite of easy access to sources was met by the long ago (as early as in the "pre-information" age) introduced system of collective administration of author's and related right (though not other intellectual property rights). ${ }^{11}$ That system, expressed by law, is based on the simple "jukebox principle": "insert a coin, get law".

Both the above mentioned values (information mutuality even more) are based on mutual sharing of information including mutual sharing of human feel-

11 This system has been functioning in the Czech territory for almost a hundred years, since 1915. On some related historic issues, also critically, see Telec, I.: Autorský zákon. Komentár. Praha: C. H. Beck 1997, p. 379-397. Commentary on the previous copyright act of 1965 . 
ings about it and also on the technology of circulation of information, relatively easy for the consumer. Therefore, there are entwined politics and technology, with publicly accessible (democratised) scholarship in between. Thus we speak about the entire culture of sharing of information, which of course holds its own subcultures, including an information underworld.

Application of the information society values in practice brings along not only expressions of virtues, but also expressions of human vices. In particular, it is an infinite greed, manifested in avarice for others' property values, connected with others' talents, others' personal abilities, expended work, effort and money, under a transparent veil of "information freedom", while using appropriate ideological phrases. The subject-matter of the issue lays in the fact that the expressions of greed are applied under the conditions when I do not compensate the utilisation of other's property values by anything. Hence, I only take for myself, without giving anything in return. As if it was done by the communist slogan "to each according to his need". Such behaviour certainly causes disruptions in the objective natural relation of balance between taking and giving, consequences of which are manifested in various "superficial" economic and social disorders.

If, for example, the followers of various information ideologies - contrary to common sense and general and professional language - consider a song "information", just like weather forecast or a complex technical invention, they miss, among others, one important fact from the field of morals (and law). If somebody utilises another's song for his own economic benefit, for example as a jingle for his commercial service, a trailer or at promotion of his goods, then he exploits the results of another's talent, with which he may not be endowed, for the purpose of gaining his profit; albeit from a purchased recording. In such a case it is honest for the economic user to provide compensation to the composer, (for his exploitation another's property), usually in the form of an adequate reward (author's fee or royalty). When exploitation of another's song is concerned, for the purpose of one's own profit, then compensation in money is quite adequate, since it corresponds with the nature of profit on the side of an economic value increasor. The author may live on royalty proceeds (or draw for his life and occupation) and continue his music creation as a job while socially secured, and he may offer his works to the public for general benefit as well as economic utilisation (exploitation) for the purpose of others' profit.

This applies similarly to exploitation of performances by performing artists or of recordings by their makers (producers), which occur parallelly upon using the piece of music from recording. ${ }^{12}$

12 Some political "recommendations" from the ideological pot of e.g. Czech Pirate Party, that the performing artists should make a living only from live performances, have the nature of social engineering of the rudest kind, politically dictating people how they should behave. The position of e.g. studio musicians is not taken in account here, to say nothing about human freedom in general. On similar issues see the party's portal at http://www. 
In general, there is nothing unfair in the above outlined conditions. Just to the contrary! When you make money from another's property, you should fairly compensate the one who by his effort enables you to do that! Remember that also the creators and investors intend to gain an adequate profit from their talent or investments in the products. The purchase price paid by the customer for a loaded music carrier, or paid Internet downloading or watching fee does not solve the cases of "next" economic utilisation of others' products for the market customer's own profit.

\section{Political freedom and intellectual property}

Let's start with a rather different issue that concerns the Internet in general.

I mean the public subjective "right to Internet access" which is a part of the constitutionally guaranteed freedom of expression and opinion and right to seek, receive and impart ideas and information, as well as a widely conceived right to freedom of assembly, regardless of frontiers through any media, therefore including technical assistance by the electronic communication network (Article 17 of the Charter).

Some states like France, Finland, Estonia, Greece or Spain recognise the right to Internet access as a human right. The Czech Constitutional Court has touched this constitutional question only marginally. ${ }^{13}$ In brief, the "right to Internet access" is understood as a right to communicate with other people (or the State) in a certain, nowadays common technical way, through electronic networks. Therefore, 'disconnecting from the Internet' shall mean a non-inconsiderable restriction of execution of that right. Rather exceptionally, in a person reliant completely or mostly on this means of communication with the surrounding world, (e.g. sick or handicapped people), even an obstacle form execution of right could be considered.

Of course, like anything else, the political freedom of expression and political right to seek and impart information may be constitutionally restricted. Among others, by the protection of the rights and freedoms of others. Political, technical and legal environment of an "information society" itself does not change anything in possible constitutional restriction of political rights, as well as of "digital" political rights. This is given by the fact that all well-established general human 'pre-information' and 'out-of-information' values remain valid in an 'information society' These concerns, for example or maybe in particular, the protection of privacy.

pirati.cz/, [quoted on 25. 1. 2013].

13 Cf. the Constitutional Court Senate judgement of 7. 4. 2010, file No. I. ÚS 22/10. While the high court in Olomouc ruled that Internet and cable TV fees are of an entirely dispensable nature, the Constitutional court concluded that such an interpretation would lead to encroachment upon personal right of the petitioner. Cf. concurring opinion by Constitutional Court justice Janů. 
The opposite of the idea of limitation of the political right is usually information - political ideology that is in some respects distinguished by almost 'fetishisation' of a mere technical instrument, which is the Internet (network of electronic communications), and which in extreme variants aspires to a 'new world', relatively close to certain communist visions.

Obviously, human rights do exist in the contemporary information society. The exercise thereof is in particular distinguished by increased level of moral and legal responsibility, because misuse of e.g. freedom of expression to the detriment of others is especially in an information society 'unbearably light' and spread worldwide. It is in the technical 'lightness' where the 'unbearability' of temptation lies. In its essence, concerned is nothing but temptation of our 'technical' reason, or cool reason, sometimes inducing us up to the misuse of one of human instruments at one's pleasure and greed, to the detriment of others. Or, we may say, concerned is the temptation of 'technical' reason towards heartlessness and ruthlessness. In other words, towards suppression of one's own soul and its inner perception through conscience.

The political right to impair information of all kind, also in the world-wide technical network of electronic communication and by the technical means thereof, is temporarily constitutionally restricted, by preferred protection of intellectual rights of others. However, this is done only for a limited period of time, during which those rights apply, while it is necessary to distinguish the particular kinds of rights. ${ }^{14}$

Similarly, intellectual property enjoys constitutional protection; Art. 11 and 34 section 1 of the Czech Charter; see also Art. 17 section 2 of the EU Charter of Fundamental Rights, within the right to property. The constitutionally permitted restrictive measures in relation to political freedoms or rights in favour of intellectual property rights of others, are in a democratic (or other) society essential in particular so that intellectual property of others, often very fragile, could arise at all and exist undisturbed, thus bringing fruit and broad benefit not only to their creators and investors, but consequently to the whole society, whose culture, science and technology it enriches and develops.

Obviously, political freedoms and rights are apparent values which are in particular politically emphasised in a 'democratic' (people-governed) society, in which everyone has the opportunity to participate in administration of political (public) issues. However, political freedoms and rights cannot be (either in a democratic society) artificially lifted out of the constitutional context that is distinguished by cohesiveness, thoughtfulness and balance.

14 For example, trademark law privilege is renewable always after ten years, also repeatedly, which means a potential option of permanency of the privilege, which corresponds with the protection of the public from the possible mistaking of trademarks. On the contrary, the industrial law privilege of applied design lasts for only four years with the possibility of renewal up to twice by always three years; it may therefore last maximum ten years in total. 
I definitely may seek information about the new entertaining movie and freely impart such information, perhaps as concerns casting of the female lead role, in a discussion with my janitor or at the barber's, or on the Internet. However, this does not mean that I may make the artwork as such accessible to the public. By doing so I would have crossed the threshold of another's private autonomy. There applies that "all kinds of information are alike".

A temporary limitation of the right to impart information as a consequent effect of intellectual property rights is not without exceptions.

The legal order lays down a number of events where it is reasonably permitted to encroach upon another's intellectual rights, even against the will of the owner of the right and regardless his will. He may not even learn about it. Concerned are numerous special cases where in legal balance the lawmaker gave preference to general or public interests (e.g. to general benefit from science development or to otherwise generally important arrangement of conditions) over temporary subjective private rights exercised for commercial purposes. For example, the Czech copyright law recognises 18 such cases (in addition to the free use of the work for non-commercial personal need); e.g. legal licence for the disabled or for social care facilities. We may also mention experimental legal licence in copyright law, the use of which plays an important role at research, etc. ${ }^{15}$

Besides these legally permitted and determined cases there exist penetrations into temporary private industrial rights on the basis of official (forced) licences in general interests, for example for the purpose of the protection of public health, or for the benefit of developing and least developed countries, etc. Also, international copyright law enables introduction of official translator's licence to foreign works (in here abandoned in early 1990's due to both non-use in practice and a certain political inappropriateness towards foreign countries).

In this context we must mention the already well-established European institute of exhaustion of subjective intellectual property rights that represents restriction of their execution (while continuation thereof being preserved) in favour of general benefit from the single market within the European economic space. Even though world-wide exhaustion of those rights does not exist, ${ }^{16}$ we may come across with it in some non-European bilateral trade agreements. ${ }^{17}$ In essence, there is nothing in it but $a$ result of balancing the conflict of territorial subjective private rights (including temporal trade monopolies in industrial property) with

15 For an overview see the author's lecturing slides concerning Intellectual property rights in information society, presented in the electronic communication network at Elportál, operated by Masaryk University in Brno, in addition to author's previous slides and texts.

16 Cf. Art. No. 6 of the Agreement on Trade Related Aspects of Intellectual Property Rights, annex to the Agreement establishing the World Trade Organisation (WTO), (notification No. 191/1995 Coll.).

17 Se e.g. bilateral international exhaustion of the copyright and related rights, based on the Free Trade Agreement between the non-communist China (Republic of China) and Panama of 2003, (Art. 16.03). 
the supranational general benefit of the unified (or mutual) market. At least indirectly, exhaustion of intellectual property rights thus contributes to the freedom of information.

Therefore, from a long-term view, the whole system of intellectual property is in principle well balanced and just as concerns legislation.

Obviously, details, possible errors or extension of exceptions may be further discussed from both legal and political viewpoints. I myself have several long-term professional inducements in this field for the benefit of the public, for example the Czech introduction of copyright legal licence to parodies etc., which reflects the general need of the execution of the right to free expression (even in the case of artistic parody), also as concerns expression of a political content, which EU law expressly admits.

I emphasise that intellectual property rights are absolute property rights, which are limited both in time and territory, which means that the political right to impart information is not prejudiced permanently and usually not everywhere. Moreover, the political right to impart information inclines, in is content and meaning, toward communication, receiving and exchange of political opinions (in a broad sense), for the reason that from the constitutional viewpoint it is a "political" vertical right of a citizen toward the state, which is, at least indirectly and potentially, related to political competition for the state power.

In addition, some intellectual property is, due to its nature, determined to public use from the beginning. We therefore speak about public goods, such as designation of origin (České sklo), geographical indications (Hořické trubičcy) or guaranteed traditional speciality (Špekáček), accompanied with scientific inventions open to the public. Even though they are subjects of law, intangible assets in the legal sense of the new Civil Code, no-one may enjoy any subjective private (or public) rights toward them, since they are no-one's assets. In a legal sense, publicly (generally) shared well-being is concerned, grounded in the special nature of indication of geographical origin in particular, and of traditional origin of goods. 'Only' prohibition of deception applies here.

\section{Politics, art, science and technology}

As concerns intellectual property rights (in private property) with horizontal effect, unlike political rights with vertical effect, there applies that they are proprietary rights - beside natural human personal rights -, that are not related to policy whatsoever.

On the other hand, what is related to the non-political proprietary rights, is economic competition in the struggle for market power. Not the political competition in struggle for state or other public power. The "struggle for power" itself, no mater how threateningly the expression may sound, does not have to be anything 
wrong, if performed in a decent, respectful way, for the benefit of the public and one's own, and in a legal and right manner. ${ }^{18}$ The gained power is binding then.

Individual conflicting cases from the practice, as for example dissemination of a documentary film (artwork), in which the content of temporal political message in its meaning prevails over film (artistic) rendering and over economic investment, are legally treated in a predictable manner, with respect to circumstances of the particular case. It means with the use of generally recognised and reviewable methodology, such as jurisprudent assessment (test) of symmetry between the objective and means, which is based on legally and methodologically grounded consideration of the colliding values (rights).

Here belongs, for example, the particular case of colliding preference of the freedom of expression (debate on a public issue of general political nature), concerning the placement of an American radar in the Czech Republic, over the subjective private copyright to artwork, which was affected by a political satire within a political debate on the public issue, in which the artist participated at his freely expressed political will. ${ }^{19}$

Therefore, we may speak about generally balanced constitutional system that considers common coexistence of various rights and freedoms in the environment of cultural diversity, i.e. rights and freedoms that may possibly collide otherwise. The reason is the necessity of mutual respectful coexistence of people. Potential misuse of the market power (or political power) is prosecuted by usual legal (or political) means.

Let's in our thoughts distinguish policy (in a broad sense) on one hand, and art, science and technology on the other hand. If we use, not quite rationally though, the general term "information" for all that, we get an entirely heterogeneous mixture and we are very likely to face many social misunderstandings.

However, I am not at all trying to avoid moral and consequently legally-political discussions, for example as concerns shortening the period of protection of some proprietary rights of intellectual property, even though the modern lawmakers political tendency in Europe goes in the opposite direction. ${ }^{20}$

18 The struggle for market power as such is not autotelic, since at least indirectly it is determined by general benefit (usefulness) of products and services.

19 On a general level, the case is professionally depicted in: Telec, I.: O americkém radaru a sovětském kosmonautovi. (On the American radar and soviet cosmonaut) In: Bejček, J. Kožiak, J. (eds.): Pocta Petru Hajnovi k 75. narozeninám. Praha: Wolters Kluwer ČR 2010, p. 335-340.

20 For example, the fact that the legal fiction of literary artworks applies to computer programmes means materially (technically) absurdly long duration of the author's proprietary rights to them, seventy years after the programmer's death. 


\section{Digression to popularisation of a piece of art}

The outlined issue of free circulation of information may be rather close to the question of so far protected works of art that, however, have become popular, generally known or generally characteristic (not only for the author's creative handwriting) or have become famous or even merged with the cultural countryside which it has co-created, etc. I mean not only various songs or their lyrics like the compositions by Fanoš Mikulecký (Vinečko bílé, etc.), but also a specific architectural work, as it is expressed by the building of the television transmission tower and hotel on mount Ještěd in northern Bohemia and its two-dimensional, artistically impressive image, placed in one partition of the coat of arms and flag of the Liberec Region (and not only there).

In such cases the author must take in account that the published "famous piece of art" may live "its own separate life", through which a certain author's "tax for fame" may appear, as a part of the author's creative destiny.

On the other hand, there ought to be explained why the author of a so far protected artwork, that has ("unfortunately") become "national wealth" or became popular whatsoever, should suffer from another's commercial or economic exploitation of his generally known or popular work, without being entitled to a fair share in another's economic revenues which the author has helped to generate, at least indirectly, not to mention respect to the free will of the author's, who does not necessarily have to be willing to be related (even through his personal creation) to another's economic, political or other activity. The public may come to believing that the author ideologically identifies himself with this foreign activities or even directly supports them.

\section{Anonymous protest movement}

In conclusion, let's go back to the introduction of this paper that concerns the Anti-Counterfeiting Trade Agreement (ACTA) and its wider social context.

I would like to remind another important and current issue which concerns various protest movements on the Internet and in the streets. ${ }^{21}$ From time to time I cannot get rid of the impression of mass psychosis, almost hysteria of still immature people, to whom the "evil States" and "evil corporations" told that they would have to pay for their toys and save up for them from their pocket money. Off the topic, I recall the "traditional" street violence at the summits of the International Monetary Fund and World Bank Group. However, I do not claim that the establishment critics cannot be right in some points. Therefore, it is necessary to listen also to the outragers.

For example, what bothers me about the Anonymous Western Internet protest movement is the fact that it is anonymous. The fact is that the freedom of

21 A wide insight to the Anonymous movement, see Olson, P.: Jsme anonymní. Prague: Práh 2012. The English original (We Are Anonymous) was published the same year. 
expression is often exercised anonymously over the Internet, or under code names. I consider such an attitude an expression of personal irresponsibility and immaturity of personality. Instead of a piece of nobleness, at least.

Perhaps with the exception of an anonymous petty factual note, everyone should openly hold his ground as concerns one's political or other opinions and should bear the responsibility even for his possible publicly expressed errors or mistakes. On one hand, we often hear quite correct calls for openness of the Internet and we worry about it. On the other hand, we hide ourselves in comfortable anonymousness, because we do not want to be responsible for our actions. The Internet issues are public issues; the same applies to every Internet movement.

The movements like the Anonymous are socially and morally characteristic by escape from personal responsibility through hiding in an anonymous crowd. Unfortunately, some movements at the same time do not avoid violence on the State or public property. Their victims are often private entrepreneurs, for example administrators of intangible property or other's rights protectors, whose free attitudes and actions ideologically bother the movements. If we want our own freedom, we must first recognise the freedom of our neighbours.

I remind the violent attack on the Slovak government server in early 2012, led by the political motif to scare off the state from a political step, which was the accession to the Anti-Counterfeiting Trade Agreement. ${ }^{22}$ Fortunately, the attack lasted only for about two hours and happened during the weekend. Nonetheless, the next wave of violence happened in the Czech Republic and France. A part of Poland was in a rage as well. However, the future violence may last longer and may cause public disturbances, affecting everyone. Perhaps this is the very purpose - to raise chaos in the "society of webs" and drive a wedge between parts of the ordinary human society. For example, at the moment when the State refuses to act by somebody's political ideology. The State that is not alert as concerns the Internet is a considerably weaker party in the cyberspace. Every weak one must be protected provided that he has not caused such conditions by his own incompetence and negligence; e.g. by negligent public administration.

The recent violence on the State including the Czech Chamber of Deputies and some private entrepreneurs has nothing in common with the constitutionally guaranteed political right of resistance (Art. 23 of the Charter). On the contrary, under defined and quite extreme circumstances the right of resistance could be used against the attackers on the State. It is of no importance that the scope of the violence is low so far and rather an exhibitional one. It is definitely a demonstration of power over the State administration bodies and over the Constitution. Technical tools are a weapon of its kind. After all, also the Communists, who are ideologically close to some intellectual property opponents, demonstrated their political strength by marching with weapons during the Czechoslovak political crisis in February 1948. Only the kinds of weapons differ.

I am afraid that the outlined topic is rather a serious one.

22 Slovakia did not sign the Trade Agreement. 